Digitalizacja archiwalnych numerów czasopisma naukowego Analecta Cracoviensia 1-24 (1969-1992)

i ich publikacja w otwartym dostępie - zadanie finansowane w ramach umowy 672/P-DUN/2017 ze środków

Ministra Nauki i Szkolnictwa Wyższego przeznaczonych na działalność upowszechniającą naukę

\title{
CHRISTUS IN QUO OMNIA CONSTANT \\ Koncepcja Chrystusa Uniwersalnego \\ u P. Teilharda de Chardin
}

Chrystus stoi w centrum myśli P. Teilharda de Chardin. Jego imię wieńczy Teilhardowską próbę syntezy dziejów wszechświata oglądanych przez pryzmat nauk przyrodniczych, przez pryzmat pragnień i dążeń człowieka XX wieku i przez pryzmat wiary chrześcijańskiej. Główny trzon dzieła Teilharda stanowi ukazywanie, w jaki sposób zarówno wyniki badań naukowych jak i najżywotniejsze pragnienia ludzkości wskazują na jakąś ostateczną rekapitulację wszystkiego w jednym centrum, w jednej Osobie. Kim jednak dla niego jest ta superosoba, ten Chrystus Uniwersalny, przeczuwany przez współczesnego człowieka a poświadczony przez objawienie chrześcijańskie?

Chcemy w paru krótkich punktach przedstawić główne cechy obrazu Chrystusa wyłaniające się z pism P. Theilharda de Chardin i spojrzeć na ten obraz oczyma teologa, a więc $\mathrm{w}$ świetle interpretowanych przez Kościół danych Objawienia. Z tego punktu widzenia nasuwają się następujące spostrzeżenia:

1. Wizja chrystologiczna Teilharda de Chardin wychodzi z dość wąskiej bazy skrypturystycznej. Teilhard najczęściej odwołuje się ogólnie do św. Pawła i św. Jana (przeciwstawiając czasem ich ujęcie ujęciom synoptyków). W nauce św. Pawła głównym źródłem jego inspiracji są fragmenty 1 Kor 15: „A gdy już wszystko zostanie Mu poddane, wtedy i sam Syn zostanie poddany Temu, który Synowi poddał wszystko, aby

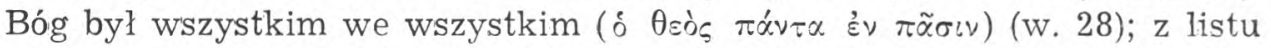
do Rzymian (8, 19-22) o całym stworzeniu, które ,,z upragnieniem oczekuje objawienia się chwały synów Bożych", aby wyzwolone z marności uczestniczyć w ich chwale; z Listu do Efezjan (4, 10): „Ten, który zstąpił, jest i Tym, który wstąpił ponad wszystkie niebiosa, aby wszystko napełnić (ut impleret omnia)", przede wszystkim jednak hymn z pierwszego rozdziału Listu do Kolosan, w nim zaś zwłaszcza wiersz 17 (cytowany przez Teilharda zawsze po łacinie): „Omnia in ipso constant (wszystko w Nim ma istnienie)". Ten wiersz staje się dla Teilharda najbardziej podstawową prawdą chrześcijaństwa. Dużą trudność natomiast stanowi dla 
niego w nauce św. Pawła doktryna o ,pierwszym Adamie” i grzechu jako źródle śmierci.

Trudno znaleźć u Teilharda dosłowne cytaty z Pism Janowych. Inspirującą rolę odgrywa głównie Prolog Ewangelii i niektóre przenośnie i obrazy Apokalipsy (Chrystus - alfa i omega; Jeruzalem Nowe, którego lampą jest Baranek).

2. Chrystologia Teilharda opiera się na dwóch niepodważalnych, jego zdaniem, fundamentach. Jednym jest prawda o Chrystusie, który stanowi zasadę, centrum, fundament całego świata stworzonego, drugim jest ewolucyjny obraz wszechświata, na który rozciąga się owa bytowa więź wszystkiego z Chrystusem:

„Są chwile, kiedy człowiek niemal traci nadzieję na wydobycie dogmatów katolickich $\mathrm{z}$ geocentryzmu, w ramach którego się narodziły. A jednak jedno jest w credo katolickim pewniejsze od wszystkiego: to, że istnieje Chrystus in quo omnia constant. Wszystkie drugorzędne wierzenia muszą ustąpić, jeśli trzeba, przed tym podstawowym artykułem wiary. Chrystus jest albo Wszystkim, albo niczym" ${ }^{1}$.

To twierdzenie, sformułowane w tak radykalnej formie w $1920 \mathrm{r}$. stanowi główną oś wszystkich dalszych prób ,wydobycia dogmatów katolickich" ze statycznego geocentryzmu i uzgodnienia ich z modelem ewolucji zbieżnej wszechświata.

3. Niektóre prawdy wiary - zdaniem Teilharda - dają się szczególnie łatwo zharmonizować z wizją ewolucji typu zbieżnego. Zwłaszcza prawda o zjednoczeniu wszystkiego w Chrystusie jako Głowie nabiera pełnego sensu właśnie dopiero przy odkryciu, że ewolucja, na swej głównej linii, zmierza do powstania jednego, ponadjednostkowego (ponadludzkiego) centrum świadomości i działania, w skład którego, jako elementy współtworzące nową całość, wchodzą poszczególni ludzie, a przez nich cały świat materialny ze swymi strukturami coraz mocniej i coraz bardziej wielorako powiązany $w$ jedno; że tworzy się ponad barierami narodów i ras jedna ludzkość (,noosfera”). Chrystus Zmartwychwstały („Chrystus Uniwersalny”) stanowi właśnie - w myśl objawienia chrześcijańskiego - ów hipotetyczny ,punkt omega” postulowany przez całość „,fenomenu ludzkiego”.

Główna wartość objawienia chrześcijańskiego dla człowieka nowych czasów polega - w tej perspektywie - na twierdzeniu, że Centrum ewolucji już aktualnie istnieje, że ma charakter jednocześnie transcendentny, absolutny (prawdziwe bóstwo Chrystusa) i immanentny, jednorodny $\mathrm{z}$ całością wszechświata (prawdziwe człowieczeństwo Chrystusa),

1 Chute, Rédemption, et Géocentrie (1920), w: P. Teilhard de Chardin, Comment je crois, Oeuvres, t. 10, Paris 1969, s. 57. 
że jest to Centrum o charakterze Osoby: świadome (superświadome) i miłujące (super-Miłością); oddziałujące na świat w sposób jednocześnie transcendentny, boski (łaska nadprzyrodzona) i konkretny ,organiczny" przez Ciało Eucharystyczne i Ciało Mistyczne. Dzięki tej zasadniczej prawdzie chrześcijaństwa najgłębsze ludzkie pragnienie i dążenie do znalezienia ostatecznego sensu i spełnienia w poświęceniu swego życia dla budowy lepszego świata jutra znajduje nieoczekiwane potwierdzenie stwarzające możliwość adoracji w konkretnej postaci i współdziałania z ostatecznym Centrum i Motorem ewolucji jednoczącej.

4. Pewną trudność sprawia w tej optyce dogmat o historycznym wcieleniu, coraz bardziej oddalonym w czasie i coraz trudniejszym do sprawdzenia. Teilhard odwołuje się jednak do stwierdzenia, że aby móc konkretnie oddziaływać „od wewnątrz” na wszechświat, trzeba się w nim narodzić. Nie widzi też innego sposobu narodzenia się we wszechświecie jak w postaci jednostkowej. Wiarę w bóstwo historycznego Jezusa proponuje sformułować następująco:

„Poczyniwszy wszystkie zastrzeżenia co do sposobu, często mało krytycznego, w jaki autorzy pobożni próbowali przedstawić psychologię Boga-Człowieka, wierzę w bóstwo Dziecięcia z Betlejem, ponieważ jest ono zawarte - oraz $\mathrm{w}$ tej mierze $\mathrm{i}$ w tej formie, w jakiej jest ono zawarte historycznie i biologicznie w rzeczywistości Chrystusa Uniwersalnego (je crois à la divinité de l'Enfant de Bethléem parce que, dans la mesure, et sous la forme où celle-ci est historiquement et biologiquement incluse dans la réalité du Christ-Universel), do którego w sposób bardziej bezpośredni zwraca się moja wiara i moje uwielbienie" "2.

Przewidując $w$ przyszłości coraz mniejsze zainteresowanie historycznym Jezusem, Teilhard przyznaje, że jeszcze dziś cała ogromna energia uwielbienia i miłości nagromadzona w Kościele („phylum chrześcijańskim") istnieje faktycznie i jest psychologicznie możliwa tylko dzięki adoracji historycznej osoby, która jest zapoczątkowaniem Chrystusa Uniwersalnego.

5. Zasadniczy opór stawia myśli Teilharda dogmat o Odkupieniu i związany z nim dogmat o grzechu pierworodnym. Teilhard nigdy nie rezygnuje z prób włączenia go w całokształt swego rozumienia chrześcijaństwa jako „religii Ewolucji”. Przede wszystkim w misterium Krzyża stara się podkreślić aspekt pozytywny: nie tylko i nie tyle naprawienie winy, lecz przede wszystkim bolesny, twórczy wkład Boga-Człowieka w zwycięstwo jednoczących sił ewolucji nad siłami bezwładu i rozkładu nieuniknionymi $\mathrm{w}$ świecie stwarzanym $\mathrm{w}$ długim procesie:

2 Introduction d̀ la vie chrétienne (1944), tamże, s. 187. 
„Krzyż, który o wiele bardziej niż ekspiację za winę symbolizuje wzrost dzieła Stworzenia przez trud.

Krew, która krąży i ożywia bardziej, niż jest przelana.

Baranek Boży, który niesie, wraz z grzechami, ciężary postępu świata.

Idea Przebaczenia i ofiary przemieniająca się przez wzbogacenie samej siebie w ideę Wypełnienia i Podboju.

Mówiąc inaczej: Chrystus-Odkupiciel dopełniający się, bez żadnego pomniejszania Jego cierpienia, w dynamicznej pełni Chrystusa poruszającego Ewolucję (Le Christ-Rédempteur, autrement dit, s'achevant, sans rien atténuer de sa face souffrante, dans la plénitude dynamique d'un CHRIST-EVOLUTEUR)" " .

Taki kierunek przewiduje Teilhard dla myśli i pobożności chrześcijan nowych czasów.

6. Pozostaje jednak element samego spłacenia długu Adamowego, zrównoważenia - jak się najczęściej wyraża Teilhard - zła moralnego przez cierpienie Chrystusa. Teilhard nie neguje nigdy tej prawdy; nie może się jednak pogodzić z tym, by miała ona stanowić najważniejszy aspekt chrześcijaństwa - takie ujęcie jest, jego zdaniem, związane w sposób konieczny jedynie ze statycznym modelem świata, w którym ponieważ został stworzony przez Boga od razu jako wykończony i doskonały - jedynym możliwym źródłem zła jest zepsucie ustalonego ładu przez bunt człowieka, a najważniejszym zadaniem - naprawienie wynikłych stąd szkód i przywrócenie pierwotnej harmonii. Tymczasem w świecie rodzącym się mozolnie z bezładnej mnogości do uporządkowanej jedności w Chrystusie, zło jest nieuniknionym następstwem samego gestu stwarzania, to znaczy jednoczenia wbrew naturalnym tendencjom rozkładu (prawu najmniejszego oporu). Teilhard lubi tu cytować Mt 18, 7: „muszą przyjść zgorszenia”. W tej perspektywie Krzyż Chrystusowy jest symbolem i historycznym ukonkretnieniem zaangażowania się Boga w przezwyciężanie tendencji rozkładowych (wyrażających się na płaszczyźnie ludzkiej w grzechu) za cenę cierpienia i śmierci prowadzącej do nowej, pełniejszej syntezy.

7. W wizji Teilharda Stworzenie, Wcielenie i Odkupienie stanowią trzy aspekty jednego procesu dokonującego się na przestrzeni całych dziejów. Konkretne wydarzenia (upadek pierworodny, historyczne wcielenie, śmierć i zmartwychwstanie Jezusa) mają w nim tylko znaczenie punktów początkowych, czy nawet tylko uwyraźniających, reprezentujących to, co w istocie dokonuje się stale, dopóki Bóg nie stanie się wszystkim we wszystkim. Zwłaszcza w perspektywie prawdopodobnego istnienia we wszechświecie wielu centrów świadomości refleksyjnej te histo-

3 Le Christ-Evoluteur (1942), tamie, s. 172. 
ryczne, konkretne reprezentacje wydają się mieć znaczenie w skali kosmosu jedynie lokalne.

8. Chrystologia Teilharda jest zasadniczo a-trynitarna. Chrystus Uniwersalny jest nowym imieniem jedynego Boga zastępującym stopniowo w świadomości i pobożności obraz Boga-Ojca związany z neolityczną kulturą rolniczą i statycznym modelem świata. Teilhard nie odrzuca dogmatu o Trójcy Swiętej. Najczęściej go nie wspomina. Istnieje tekst z r. 1939, w którym zdaje się wiązać jego znaczenie jedynie ze statycznym modelem świata ${ }^{4}$. Teoria osób i natur w Bogu i Chrystusie należy, w myśl tego tekstu, do ,skomplikowanej teologii metafizycznej”, która stoi przed problemem konstrukcji racjonalnego schematu statycznego zachowującego jednocześnie i względną niezależność i współzależność „Ja” boskiego z ludzkimi ,,ja” jednostkowymi w i przez „Ja” Chrystusowe. Jedyny rozwinięty tekst dotyczący wprost tajemnicy Trójcy Swiętej i Jej roli w dynamicznym (ewolucyjnym) rozumieniu chrześcijaństwa (tekst o 5 lat późniejszy od poprzedniego) przyznaje tej tajemnicy specyficzną rolę także wobec najbardziej aktualnych potrzeb religijnych: jest ona istotnym warunkiem tego, by Bóg mógł być osobowym i, mimo wcielenia, transcendentnym szczytem wszechświata dążącego do personalizacji:

„Gdyby Bóg nie był 'troisty' (to znaczy gdyby nie przeciwstawiał się wewnętrznie sobie samemu) nie pojmowalibyśmy, jak może istnieć sam w sobie (qu'il pût subsister sur soi) niezależnie i bez oddziaływania z jakimś światem wokół siebie; i jeszcze: gdyby nie był troisty, nie pojmowalibyśmy także, że może stwarzać (a więc wcielać się) nie zanurzając się bez reszty w świecie, który wzbudza do istnienia" ${ }^{5}$.

Teilharda interesuje jednak stale nie samoistność Boga, lecz właśnie Jego związek z wszechświatem, nie wolność Boga w akcie stworzenia, ale konsekwencja i wewnętrzna logika rozwoju stwarzanego dzieła stąd stałe u niego ograniczenie spojrzenia na Chrystusa do Jego relacji ze wszechświatem rozumianym jako organiczna całość.

Podsumowując: Zwrócenie przez Teilharda uwagi na Chrystusa jako na Tego, w którym wszystko ma istnienie (in quo omnia constant) rozpatrywane wewnątrz całej nauki katolickiej, przy założeniu w szczególności całej tradycyjnej chrystologii, może prowadzić do ważkich pytań i do istotnego wzbogacenia naszego rozumienia wiary. Spojrzenie na Chrystusa od strony Jego jednoczącej roli rozciągniętej na całość stworzenia może słusznie zafascynować i stać się dla człowieka dziś ważną pomocą w przyjęciu Objawienia. Ograniczenie jednak depozytu wiary do tego tylko, co Teilhard proponuje niekiedy jako „religię przyszłości”,

${ }^{4}$ Quelques vues générales sur l'essence du Christianisme (1969), tamże, s. 155.

5 Introduction à la vie chrétienne (1944), tamże, s. 186. 
byłoby wielkim zubożeniem. Nie można wprawdzie od czasu Teilharda ominąc pytania o teologiczny sens przemian zachodzących we Wszechświecie rozumianym jako całość i nie sposób nie przyznać Chrystusowi uwielbionemu centralnego miejsca w dziejach, kluczowej pozycji wzgledem każdego dokonującego się $\mathrm{w}$ nim rozwoju - w jakimś więc sensia pojęcie Chrystusa-Uniwersalnego czy Chrystusa-Ewolutora powinno znaleźć swe miejsce w chrystologii, przynajmniej jako pytanie. Trudno byłoby chyba jednak zawrzeć w tym pojęciu całe bogactwo wyznania wiary w Jezusa jako Chrystusa i Pana. W każdym razie bez prawdziwej i żywej w świadomości wierzącego tożsamości Chrystusa Uniwersalnego z konkretnym Człowiekiem, który z miłości oddał swoje życie za nas, gdv byliśmy grzesznikami, bez Jego tożsamości z odwiecznym Synem Ojca, który w jedności Ducha Swiętego daje nam dostęp do samej głębi tajemnicy Boga, ów Chrystus Uniwersalny byłby nieokreślonym tworem: ni Bogiem ni człowiekiem.

Zdanie „wszystko w Nim ma istnienie” jest niewątpliwie twierdzeniem objawionym o wielkim znaczeniu chrystologicznym. Wzięte jednak w oderwaniu, a zwłaszcza zinterpretowane tylko w świetle kosmologii (choćby najtrafniej tłumaczącej dane nauk szczegółowych i intuicje ludzkiego serca) nie stanowi jeszcze samo najbardziej podstawowej i ostatecznej prawdy chrześcijaństwa.

\author{
CHRISTUSS IN QUO OMNIA CONSTANT \\ Conception du Chrisit Universel chez P. Teilhard de Chardin \\ R̊ é s u mé
}

En regardant, en thécilogien, la fligure du Christ ébauchée dans les écrits de P. Telithard de Chardin, on constate ce qui suit:

1. Sa vision du Christ ne se base que sur quelques fragments des épîtres de S. Paul: 1 Cor 15, 28; Rom. 8, 19-22; Eph. 4, 10; Col. 1, 17 et sur quelques images prises de l'Apocalypise de S. Jean.

2. Elle a, notamment, un double fondement: la vérité rêvélée qu'en Christ „omnia constant" (Col. 1, 17) et la vision de l'Univers en évollution qui doit être supporté, pénétré et régie par le Christ.

3. Le Christ c'est donc surtout le Centre personnel, actifif, transcendant et, à la fois, immanent de la convergence de l'évolution cosmique.

4. L'incarnation historique est vue comme un commencement de l'influence immanente du Christ dans l'Univers, un point qui, en s'éloignant danis le temps, perdera de plus en plus son importance dans l'adoration et l'amour chrétiens. 
5. C'est l'aspect posistif d'un effort doruloureux die conquête e't non pas l'aspect de la rédemption qui est mis en évidence dans le mystère de la Croix.

6. Le dogme de la chute originelle fait la plus grande difficulté à la conception de Teilhard. Le mal, même le mal moral, semble être inévitablement lié au monde en pleine évolution, et, alors, le sens des souffrances du Christ esit plutôt celui de vaincre les forces de l'inértie inhérentes au mande et non pas celui de restaurer un ordre détruit.

7. La Création, l'Incarnation et la Rédemption ne font que trois aspects ru même myistère de l'histoire du Cosmos. Les événements concrets de cette histoire (la chute origlinelle, la nailssance de Jésuls, sa piasision et sa résurrection) ne sont que les points initiaux ou réprésentatifs de ce qui se passe toujours. Leur influence imméldiaite esst, peut-être, limitée à une seule région du Cossmos.

8. Le Christ Universel n'est pas, normallement, considéré dans ses relations trinitaires. Elles ne sont mentionnées qu'une saule fois comme nécessaires pour établir une transcendance permanente du Dieu qui s'est incarné dans le monde.

En conclusion: le Christ-Universel tel que Teilhard le présente pose, pour toujours, devan't la théologie, la question du rôle unitif primordial du Christ ressuscité dans l'univers récréé en lui. Restreint aux limites de ce que Teilhard présente parfois comme, ,la religion de l'avenir", il ne contient pourtant pas toutes les richesises de la confession chrétienne: Jésus est le Christ. 